\title{
TUBERCULOSE: SOFRIMENTO E ILUSÕES NO TRATAMENTO INTERROMPIDO'
}

\author{
TUBERCULOSIS: SUFFERING AND ILLUSIONS IN AN INTERRUPTED \\ TREATMENT \\ TUBERCULOSIS: SUFRIMIENTO E ILUSIONES EN EL TRATAMIENTO \\ INTERRUMPIDO
}

\author{
Wilma Suely Batista Pereira ${ }^{2}$ \\ Carlos Bezerra de Lima ${ }^{3}$
}

\begin{abstract}
RESUMO: Estudo realizado em Porto Velho (RO), junto a doentes de tuberculose que interromperam o tratamento. A partir da abordagem qualitativa e do método hermenêutico-dialético de análise do material das entrevistas, foi possivel inferir que os sujeitos deste estudo têm pouco conhecimento sobre tuberculose e tomam atitudes relacionadas ao impacto que o diagnóstico e o tratamento prolongado causaram a eles próprios e ao seu meio social. Para os doze entrevistados, a interrupção do tratamento relaciona-se a motivos enraizados no não-dito, efeitos colaterais dos medicamentos, desorganização dos serviços e ilusão de estar curado. Isto implica repensarmos nossas posições técnico-metodológicas e as relações profissional-doente, visando a uma abordagem que possibilite encararmos tuberculose-interrupção de tratamento como experiências vividas pelas pessoas, familias e redes sociais por elas tecidas ao longo do tempo.
\end{abstract}

PALAVRAS-CHAVE: tuberculose, interrupção de tratamento, Saúde Coletiva.

\section{APRESENTAÇÃO DO PROBLEMA}

Em nossa experiência profissional, trabalhando em unidades básicas de saúde, chamounos à atenção o portador de tuberculose e seu comportamento frente ao tratamento da doença. Questionamos como essas pessoas encaram a doença e porque muitas delas abandonam o tratamento, já que atualmente podemos contar com certa facilidade de acesso aos medicamentos e aos exames de diagnóstico e controle ou seja, a interrupçăo do tratamento de tuberculose ainda é uma grande interrogação, pois, se as causas da não adesão ao tratamento fossem facilmente abordáveis e sanáveis, já teríamos resolvido expressiva parte do problema. As possiveis respostas a esses questionamentos guardam nexo com as condiçőes de miséria e desesperança em que a maioria da população vive, e com a má qualidade dos serviços de saúde.

Correndo em paralelo a tais condiçőes, há uma intrincada rede de elementos subjetivos que atuam no adoecer do indivíduo, dentre os quais, os sentimentos que o doente associa a cada sintoma que apresenta, a forma como tomou conhecimento da doença que o acomete, as experiências passadas, a maneira como as pessoas do seu meio reagem e se relacionam

\footnotetext{
1 Artigo extraído da dissertação de mestrado apresentada ao Curso de Mestrado em Enfermagem da UFPB, em 1998.

${ }^{2}$ Enfermeira, docente do departamento de Enfermagem da Universidade Federal de Rondônia/ UNIR, Mestre em Enfermagem pela UFPB.

${ }^{3}$ Enfermeiro, docente do Departamento de Enfermagem Médico Cirúrgica e Administração/ UFPB, Doutor em Enfermagem pela UFRJ.
} 
com a doença, e como os reflexos desse comportamento permanecem na história da doença em questão. A vivência do adoecer sofre interferência das diversas fantasias que o indivíduo faz de si mesmo e da maneira como se relaciona com a realidade, fazendo com que essa experiência adquira uma conotaçăo ora eminentemente solitária, ora coletiva, por todas as transformaçōes que traz para seu meio social (Alves et al.1996; Alves; Minayo,1994, Pinkus, 1988). Toda essa complexa problemática interfere na adesão do individuo ao tratamento e sua continuidade até a alta por cura da doença.

$\mathrm{Na}$ ocorrência de doenças que demandem tratamento que se estenda por um longo prazo, percebe-se geralmente um considerável percentual de desistências do tratamento. No caso da tuberculose, esta interrupçăo acarreta sérios prejuizos para os próprios doentes, para os serviços de saúde e para a sociedade como um todo. Assim, o abandono, a não adesão, ou qualquer outro termo que se dê a esta questão, configura-se como um problema de saúde pública. Teve sua origem desde que foi instituido o tratamento quimioterápico e representa, atualmente, um desafio para as unidades de saúde do mundo inteiro. Um desafio que se expressa também na necessidade de intervençăo para reduzir os focos de infecçăo e os custos do programa, para garantir a eficácia do tratamento e impedir o surgimento de resistência bacteriana (BRASIL, 1995).

Na literatura revisada, encontram-se diferentes explicações para o abandono de tratamento da tuberculose. Estudiosos como Beltran, Mosca; Cross (1983) investigaram esse fenômeno e apontaram suas causas relacionadas a desemprego, indisponibilidade das drogas nos serviços de saúde e tratamento muito prolongado, demorando a alcançar a cura. Em Salvador (BA) foram encontradas como razões mais frequientes de abandono de tratamento de tuberculose: dor no estômago, desestímulo para tomar as drogas; sensaçăo de já estar curado(a); quota de medicamentos terminada antes da consulta marcada; impressão de que a droga não fazia efeito; falta de dinheiro para o transporte; troca de tratamento oficial por outro tipo de tratamento; indisponibilidade de medicamentos no posto; referência de que a doença estava se agravando; que a medicação estava os deixando mais doentes; greve nos transportes públicos e gravidez, Sampaio; Duarte; Guerra (1994). Foram ainda encontradas em Santiago do Chile, no início da década de 90 , os seguintes motivos para o abandono de tratamento: alcoolismo, intolerância medicamentosa, problemas relacionados ao trabalho e tratamentos paralelos de outras patologias, Ferrer, Kirschbum(1991),

Costa (1996) fez um estudo de Coorte para identificar "Fatores operacionais e sociais envolvidos no abandono terapêutico da tuberculose" em instituição especializada de referência no Estado do Amazonas. Os resultados do estudo mostraram que $30,49 \%$ dos motivos de abandono estăo relacionados a fatores sócio-econômicos e $69,51 \%$ têm relaçăo direta com a operacionalizaçăo dos serviços de atendimento aos doentes, sugerindo uma explanação mais detalhada sobre a doença, a terapêutica e suas consequeências. Assim, as causas da descontinuidade no tratamento năo se esgotam em explicaçōes comumente dadas pelo doente ou inferidas pelo profissional que o assiste; há mais conhecimento a ser desvelado. Assim, nosso desejo é ouvir a voz de doentes de tuberculose. Nossa atenção neste estudo está voltada, de maneira particular, para a fala do doente de tuberculose que abandonou o tratamento, visando compreender este fenômeno sob a ótica de quem o vive. Na implementaçăo deste estudo procuramos investigar razões da interrupção do tratamento da tuberculose, a partir da ótica de doentes, e analisar as causas da interrupçăo do tratamento.

\section{CAMINHO METODOLÓGICO}

A partir dos objetivos propostos para este estudo, sua realizaçăo se deu na área de abrangência do CENTRO DE MEDICINA TROPICAL DE RONDÓNIA-CEMETRON, na cidade de Porto Velho, onde foram obtidos nomes e endereços de clientes cadastrados que 
abandonaram o tratamento. Escolhemos o CEMETRON para cenário deste estudo, por tratarse de um hospital de referência no Estado de Rondônia para o tratamento de doenças transmissiveis.

O grupo dos sujeitos participantes do estudo foi composto por doze doentes de tuberculose pulmonar classificados como faltosos ao CEMETRON, onde estavam cadastrados no Programa de Controle da Tuberculose-PCT. Foram considerados como interrupção de tratamento os casos em que o doente não retornou ao serviço, nem atendeu a sua convocação após 21 dias decorridos da data estipulada para consulta de controle e entrega da quota mensal de medicamentos, conforme determina a rotina do CEMETRON. Como instrumento de coleta, utilizamos um roteiro de entrevista semi-estruturado contendo questőes referentes aos objetivos propostos para o presente estudo, e um roteiro para observação de campo contendo pontos a observar, tais como: o desenvolvimento da entrevista, o ambiente em que a mesma foi realizada, postura, receptividade dos entrevistados.

Escolhemos essa técnica para coleta de dados por favorecer a interaçăo entre o pesquisador e os sujeitos da pesquisa, fundamental para sua qualidade (Gil, 1990). O roteiro para observação, por permitir fazer registros não percebidos mediante a técnica de entrevista. Durante a sua realização, a fala dos sujeitos em nenhum momento foi interrompida, permitindoIhes se expressar livremente, para que não houvesse interferências de nossas idéias sobre as deles. Mesmo a fala sendo livre, elaboramos algumas questőes orientadoras, indispensáveis à coleta dos materiais referentes ao modo como o entrevistado descobriu que estava doente de tuberculose, o que sabe sobre a tuberculose, o que pensa em relaçăo a ela, o motivo pelo qual deixou de tomar os medicamentos, há quanto tempo deixou de tomá-los e quantas vezes interrompeu o tratamento.

A análise dos materiais colhidos foi feita com base nos aspectos da proposta de análise hermenêutica-dialética, sistematizada por Maria Cecília de Sousa Minayo, para quem a Hermenêutica enquanto proposta interpretativa, vem sendo construída a partir da década de sessenta, nas discussőes entre HABERMAS e GADAMER, em busca de formas de objetividade e de abordar a práxis, estabelecendo uma articulaçăo entre as Ciências Sociais e a Filosofia, "como um caminho do pensamento" (Minayo, 1996, p. 218). Conforme esses estudiosos, a hermenêutica procura depreender o sentido presente na comunicação entre os seres humanos, que se dá por intermédio da linguagem. Prioriza no tratamento dos dados condições do dia-adia e procura esclarecer as estruturas profundas dessa realidade cotidiana.

A hermenêutica se dedica a perscrutar o sentido que se esconde no texto com a consciência de que às vezes o contexto diz mais que o próprio texto. Assim, interpretar um texto é ir pelas entrelinhas para encontrar aquilo que não está dito, às vezes, até negado nas linhas. Dessa forma, um discurso não é compreendido apenas na sua forma, na gramática, mas na mensagem que comunica. $O$ conteúdo de um texto não está totalmente nele, se assim fosse, não seria necessário interpretá-lo, Demo (1995). Para este autor, ler hermeneuticamente um texto é usar a compreensăo tomada como relaçăo de troca, diálogo em sua mais completa definição, em que nada é reduzido a objeto e requer do intérprete empatia, capacidade de se colocar no lugar de quem escreveu ou falou. Os dados são referências históricas repletas de sentidos, significados, preferências culturais, os quais devem ser compreendidos como a busca do equilibrio entre capacidade formal e percepção política.

Segundo Minayo (1996), inspirada em Stein, a hermenêutica e a dialética têm como pressuposto a certeza de que não há observador imparcial nem ponto de vista fora do homem e fora da história. A interpretação dialética aplicada a pesquisas no campo da saúde requer o estabelecimento das determinações fundamentais que se expressam na compreensão da conjuntura política, social e econômica em que o grupo pesquisado está inserido e sua participação como ator social, bem como das condiçőes de moradia, acesso a bens e serviços e sua distribuição geográfica, conhecimento da politica de saúde em geral e, especificamente, 
em relaçăo à instituiçăo de saúde à qual o grupo pesquisado tem acesso.

Os procedimentos de análise foram organizados de acordo com três passos sugeridos por Minayo, (1996, p. 234-6): ordenaçăo, classificaçăo e análise final dos dados. O primeiro passo consistiu na transcriçăo do material das entrevistas da fita cassete e do relatório de observação de campo para um arquivo no computador, o que já representa a primeira classificaçăo. Para proceder à classificação na segunda etapa fizemos a leitura dos materiais repetidas vezes, de modo a captar os aspectos mais importantes, as "chaves" dos discursos dos sujeitos, as quais possibilitaram adentrar nas dimensőes da interrupçăo do tratamento da tuberculose. Assim, foi se delineando o "corpus" da investigação.

A partir da detecçăo dessas "chaves" penetramos nas seguintes dimensőes da interrupção de tratamento: 1 - o sofrimento, com as seguintes dimensőes: sofrimento causado pela descoberta dos sintomas, sofrimento causado pelo tratamento e sofrimento causado pela volta dos sintomas; 2 - negaçăo / medo da doença; 3 - dificuldade financeira; 4 - revolta com os serviços de saúde. Percebemos que esses elementos ora apareciam como especificos da fase da descoberta dos primeiros sintomas, ora estavam presentes na decisão de interromper o tratamento, e/ou no momento em que os sujeitos perceberam o retorno dos sintomas. A relaçăo dos doentes com os serviços foi também um elemento presente em todas as falas. $\mathrm{Na}$ análise final dos dados tomamos como ponto de partida as falas dos entrevistados, identificadas por uma letra do alfabeto, correspondente à ordem em que foi feita aquela entrevista. Essas falas foram contextualizadas, confrontadas com o que dizem os manuais de controle da tuberculose consultados, com os procedimentos realizados no serviço onde foram coletados os nomes dos sujeitos deste estudo, e com a nossa experiência profissional.

Consideramos oportuno explicitar neste capitulo nosso entendimento sobre os conceitos de abandono e adesão ao tratamento. Talvez o termo abandono năo seja o mais adequado para expressar qualquer interrupçăo de tratamento. Esta năo é uma questăo que se possa generalizar, pois veremos particularmente neste estudo que nem sempre houve descuido com o tratamento e, se houve, nem sempre foi da parte do doente. Alguns deles interromperam o tratamento devido aos efeitos colaterais causados pela açăo das drogas, enquanto outros năo conseguiam acesso aos medicamentos por falhas na organizaçăo dos serviços: o posto estava fechado, faltando material e profissionais. Nesses casos năo houve descuido nem opçăo pessoal da parte dos doentes por interromper o tratamento. O descuido foi do serviço, que não lhes ofereceu as possibilidades de acesso aos medicamentos de maneira que pudessem prosseguir no tratamento até a cura. Na verdade o doente, vitima do próprio sistema de saúde, năo teve outra alternativa senăo a de interromper o tratamento.

O termo adesăo, tomado conforme estabelece o dicionário, implicaria uma relação delicada entre o profissional e o doente, sendo este informado e envolvido no tratamento da doença que $\mathrm{o}$ acomete. No caso da tuberculose o doente, submetido ao peso subjetivo da doença, consentiu o tratamento, deixou-se envolver, incorporou as orientaçōes recebidas e partilhou seus sentimentos e expectativas frente à própria doença e ao tratamento com o profissional que o supervisiona corta o tratamento. Entendemos que todo abandono resulta em interrupçăo, porém, nem toda interrupção é abandono de tratamento. Convém estabelecer uma aproximação criteriosa desta questão, pois năo se pode precisar quăo descuidado é alguém, sem incorrer em avaliações imprecisas e injustas. Assim, adotamos neste estudo o termo interrupçăo para os casos em que a descontinuidade no tratamento foi por motivos alheios à vontade do doente e interrupção voluntária quando ela foi uma opçăo pessoal.

\section{DIMENSŌES DA INTERRUPÇÃO DO TRATAMENTO}

O sofrimento de se descobrir doente ou o impacto que este fato causa está evidente na fala de um dos nossos entrevistados, um rapaz de 25 anos que trabalha como gari. Contou que 
havia interrompido o tratamento por duas vezes em um ano. Sobre a experiência de adoecer, deu o seguinte depoimento:

(...) Eu nunca pensei...nunca pensei em uma doença que podia entrar em mim. A única doença que eu pensava era gripe, não sabia o que era tuberculose, nunca passou na minha cabeça. Eu me senti um marinheiro de primeira viagem, que năo sabe de nada, năo procura saber de nada, essa é a verdade, eu ainda năo tinha conhecimento de doença nenhuma (...) J

Nosso entrevistado não pensava em assuntos referentes a saúde e doença, porém com o impacto dos sintomas ficou chocado. Expressa a quebra da ilusăo de invulnerabilidade que todos nós, pelo menos por algum momento em nossa vida, experimentamos. Quando começamos a sentir algum incômodo, essa ilusão cede lugar ao choque de descobrir que somos frágeis, podemos ficar doentes e até morrer.

Mesmo em meio a evidências de doença, nosso entrevistado relutava em tomar a decisão de procurar um serviço de saúde "(...) o pessoal falava e eu: 'ah, é só uma tossezinha". Adiou o assunto relativizando a importância do sintoma que já se lhe apresentava. Posteriormente, impulsionado pelo agravamento dos sintomas, começou a procura por ajuda. Esta busca foi para ele um longo periodo de sofrimento, como relata:

(...) Eu sentia muita febre, tossia muito, eu tava ruim mesmo, entendeu? Ai fui no posto, o médico não deixou nem eu contar direito o meu problema, disse que eu tinha pneumonia e passou 23 injeçőes, tomei 20 , não adiantou nada, fiquei com a bunda que parecia um melão ! ai eu fui no hospital, fazer exame, ai vim pra cá, (para a cidade de Porto Velho) fiz exame aqui, e disseram que eu tinha tuberculose (...) J

Afirma que seguiu as orientaçōes do profissional que o atendeu. $O$ que torna este caso ainda mais grave é que o diagnóstico foi errado. Fica clara a falha no atendimento que 0 entrevistado recebeu no posto de saúde, unidade que deve ter sempre o rastreamento dos sintomáticos respiratórios como conduta de rotina. Além desse atendimento, ele ainda passou por outro hospital sem lograr êxito, antes de chegar a Porto Velho e fazer exame no CEMETRON, quando então obteve o diagnóstico de tuberculose e foi orientado quanto ao tratamento.

Igualmente lamentável é que às vezes o doente tende a falar sobre a dor causada pela doença, seus medos, suas dúvidas, e não consegue. O profissional, muitas vezes, por sobrecarga de trabalho, por deficiência em sua formação quanto a relações humanas, bloqueios pessoais ou outros quaisquer motivos, năo permite que o doente dê vazăo aos sentimentos que o afligem. Esta questão se agrava especialmente no caso de uma doença infecto-contagiosa ainda tão estigmatizada como a tuberculose, que chega a incapacitar o individuo para o trabalho e até matar. Em situações como esta é preciso perguntar aos nossos governantes e aos profissionais de saúde: onde está a cidadania dos nossos doentes? Como é possivel o exercício da cidadania em situações semelhantes?

Há mais sofrimento na história da doença do jovem gari, decorrente das modificações ocorridas tanto no aspecto individual como no espaço coletivo que ele ocupa :

(...)Eu sei que não é pra tá falando muito perto das pessoas, não tá comendo uma coisa e dar pra outra pessoa a mesma coisa, acho que a saliva também, se tiver mais algum eu não sei. Não sei se é verdade, mas eu tenho pra mim que é isso (...)ninguém da minha familia pegou isso. Eu tenho cuidado, depois que eu soube, fiquei morando sozinho num quarto, lá a casa da mulher era do lado, eu não vou lá, as coisas săo tudo separado, ninguém pegou.

Ele tem conhecimento sobre como se dá o contágio da doença, tomou a atitude extrema de se afastar da familia, saindo do quarto para morar no quintal, na tentativa de não transmitir a doença a ninguém. Fica claro o abalo causado em sua familia, quando menciona que não entra em casa como medida preventiva. Sobre a decisão de interromper o tratamento, o entrevistado fez o seguinte relato:

(...)al eu vim, passei trés meses aqui, comecei a tomar os remédios, sai daqui forte, bem. (...) ai depois eu abandonei o tratamento, porque quis mesmo, foi.... a medicação era ruim 
só no começo, mas depois melhorava, o organismo acostumava. Ai fui pra casa, né? Ai abandonei, fui dançar, beber, fumar, fui fazer tudo o que tinha direito(...)

Desde que foi "sacudido" pela descoberta dos sintomas, J percorreu um caminho cheio de curvas na sua relação com a tuberculose: os desencontros na procura por respostas aos incômodos dos sintomas que o afligiam; o afastamento da familia, o tratamento iniciado e depois interrompido voluntariamente, para dar vazão aos desejos cuja satisfaçăo havia sido adiada pela descoberta da doença.

Pelo visto até este momento, a tuberculose causa impacto próprio do adoecer e também o impacto do tratamento demorado, que impõe certas restriçőes(ainda que nós, profissionais de saúde consideremos poucas) as quais, muitas vezes, o individuo năo se dispōe a observar. $O$ peso subjetivo que a doença tem, para cada indivíduo, parece estar quase sempre ligado a momentos de tensão, ansiedade, medo. A doença nos expõe como frágeis, atinge nosso jeito de ser. Alterando nossa "ordem estabelecida", altera também o nosso relacionamento com as outras pessoas.

Além do sofrimento causado pela própria doença, o tratamento em si acarreta mais sofrimento ao doente:

(...)Eu nunca penso nessa doença não, não penso não, eu já tou me tratando, não sei o que é não senhora, quando eu via o sangue (no escarro)năo sentia nada não(...) H

Neste trecho de sua fala, o entrevistado demonstra medo e desespero em relação à tuberculose. Repete que nada sabe sobre a doença, evitando pronunciar o termo tuberculose, nega o impacto causado pela presença do sangue no escarro e afirma estar fazendo tratamento, como estratégia para abreviar a conversa. Referiu sofrer de diabetes mellitus insulinodependente e queixou-se de mal-estar geral. Por ocasião da entrevista apresentava sudorese profusa, pulso filiforme e taquicárdico. A medida que a conversa se alongava, sua fala se modificou, conforme aparece no trecho abaixo:

(...)Eu me trato, é só o remédio não me ofender que eu me trato. O médico tem que passar um remédio que não ataque minha barriga... esse remédio ataca o figado, eu vomito demais, se eu agüentar eu me trato (...) $\mathrm{H}$

Este trecho de seu depoimento traz o mesmo tom de desespero, porém já admite ter parado de tomar os medicamentos, mas impőe condiçø̃es para tomá-los. Relata os efeitos colaterais causados pelos medicamentos tuberculostáticos. Refere estar disposto a continuar o tratamento, caso o medicamento seja substituido por um outro que năo lhe cause tanto mal. Seria este comportamento já um indício de exercício de cidadania por parte dos doentes? Os efeitos colaterais dos medicamentos constituem um desafio para os serviços de saúde, particularmente para os profissionais que têm uma relaçăo mais direta com as pessoas que estão em tratamento. Exige que os profissionais estejam comprometidos com o seguimento dos casos em que seja necessário o acompanhamento mais de perto. Consideramos oportuno registrar que as reaçōes adversas têm como fatores de risco: idade, alcoolismo crônico, desnutriçăo, doença hepática prévia, infecçăo pelo HIV. Porém, mesmo nestes casos, o tratamento e acompanhamento devem ser feitos nas unidades básicas de saúde (BRASIL, 1995).

Tais reaçōes săo classificadas como leves, moderadas e graves. Estas últimas săo assim denominadas de acordo com os sintomas, que podem ir desde náuseas, dor abdominal, anorexia, exantemas com ou sem prurido, ictericia, confusăo mental, até sangramentos, uremia, choque, parestesias, hipoacusia entre outros(BRASIL, 1995).

O problema dos efeitos colaterais aparece na fala de outro entrevistado, uma jovem de 23 anos, desempregada porque năo conseguia mais trabalhar: (...)Eu parei de tomar porque tava vomitando demais, ficando amarela, nåo tava nem podendo comer direito que vomitava tudo de novo(...).

Esta entrevistada também apresenta as reações consideradas adversas entre moderadas 
e graves. Os casos de náuseas, anorexia e dor abdominal estão mais freqüentemente associadas ao uso da PZA /RMP. A conduta sugerida é alteração no horário da medicação e uso de medicamentos sintomáticos, conforme a necessidade. Já a icterícia, descartadas outras causas, pode ser causada pelo uso de RMP. A conduta é suspensão do esquema e observação por 5 dias, lembrando que "a hepatotoxidade é mais freqüente nos dois primeiros meses do tratamento, embora possa ocorrer durante todo o tratamento" (BRASIL, 1997, p. 15).

O Ministério da Saúde recomenda que os pacientes sejam orientados em relação a possiveis efeitos colaterais causados pelo tratamento, bem como de interação medicamentosa. Deve ser evitada a substituição precoce do Esquema I, para a importância do ajuste da dose ao peso do paciente e para a possibilidade de individualizar o horário de administração dos medicamentos, de acordo com o conforto e disponibilidade do paciente, nos casos em que isso se fizer necessário. Outra orientação é no sentido de que não há necessidade de bulas nos medicamentos, uma vez que os pacientes deverão ser orientados corretamente na unidade de saúde. Sobre o trabalho de orientação junto ao paciente em tratamento, o Ministério da Saúde o considera um ponto primordial na prevenção da interrupção de tratamento (BRASIL, 1995).

Segundo informação do CEMETRON, G foi orientada a comparecer ao serviço depois de cinco dias, para uma reavaliação. Foi ai que se deu a ruptura, passando a entrevistada a ter uma atitude de descrédito em relação ao tratamento e não voltou mais ao serviço.

(...)Não sei se esse remédio é bom mesmo não, se a senhora me garantir que eu fico boa, posso até voltar, mas se for pra ficar do mesmo jeito já sei que eu vou é morrer mesmo(...)

Ela parece ter introjetado sua experiência aflitiva de doença, em si, somada a um tratamento que, prometendo a cura, trouxe sofrimentos a mais, como um caminho sem saida. Expressa a angústia ante aquilo que, para ela, é a proximidade da morte, lançando um desafio, quase um apelo desesperado, para que lhe garanta a cura. G estava precisando de alguém que Ihe servisse de testemunha, salvadora, cúmplice. Assim, ela compartilharia o peso do sofrimento que está passando.

Acreditamos que $\mathrm{G}$ e $\mathrm{H}$ não tenham inteira responsabilidade sobre a interrupção do tratamento e todas as consequências que isto acarreta. Afinal, no caso desses dois entrevistados havia motivos fortes para a interrupção do tratamento: os sintomas desagradáveis causados pelas reações adversas aos medicamentos. Ambos disseram, em tom de desespero, que queriam se tratar, desde que os medicamentos não lhes fizessem mal.

A vivência do sofrimento de uma doença, agravada pelo sofrimento do tratamento, a exemplo do que acontece no câncer, parece levar o individuo a optar por um dos dois sofrimentos: o tratamento ou a doença.. Na opção entre a doença e o tratamento, certamente pesa também a situação financeira da pessoa doente, na atual conjuntura do sistema de saúde, que oferece alguma confiabilidade apenas dentro dos serviços privados, e, estes nem atendem a todos os convênios; apenas àqueles que lhes forem mais rentáveis. Mais uma vez lembramos a questão da cidadania do doente.

Outra versăo do sofrimento aparece com a volta dos sintomas:

(...)Eu, pra mim, tuberculose é uma doença como qualquer outra, né? Antigamente, seria bem difícil, mas hoje parece que é uma doença bem fácil, é só fazer o tratamento de acordo, como eu fiz, né? Até fiquei bom, mas infelizmente, o que se pode fazer, né ? (...) Eu acho que a tuberculose atualmente, sendo bem tratada, é uma doença simples. A tuberculose é como a malária, quando ela ataca, ela ataca!(...) B

B compara a tuberculose a uma doença qualquer, repete o discurso que ouviu no CEMETRON sobre a facilidade de tratamento de hoje em dia, afirma ter seguido o tratamento. Mas, deixa uma lacuna com um suspiro que pode ser interpretado talvez como arrependimento e resignação. Só no final do discurso dá sinais mais claros do medo que a tuberculose lhe causa: a doença, antes simples, fácil, como outra qualquer, agora é comparada à malária. Continuando, mais um trecho de sua fala: 
(...)Ai após uns seis ou sete anos, voltou com uma outra doença, bronquiectasia. Desse tempo pra cá, praticamente, vivo no hospital. Infelizmente essa outra doença que peguei năo tem cura (...) a minha situação é essa, não posso forçar o corpo e de vez em quando recai e vou pro hospital, né? Vem a falta de ar(...)

Reafirma ter seguido o tratamento até o fim e alcançado a cura, mas a doença teria voltado, acompanhada de outra doença, que lhe fazia sentir-se enfraquecido e retornar por várias vezes ao hospital. Segundo o prontuário do Serviço, ele tinha tuberculose ainda ativa.

Depois, já na terceira vez em que o visitei no hospital, ele admitiu que havia deixado o tratamento:

(...) A mim mesmo, depois que eu deixei o tratamento, eu acredito que essa doença voltou uma parte por descuido mesmo, eu bebia muito. Foi um pouco da minha parte, porque o passado... parece que aumentou o um pouco o problema, eu acredito que esse foi o caso de voltar essa doença, a gente bebe, gosta de dançar, gosta de uma seresta, hoje dorme aqui, amanhã dorme lá, não se alimenta perfeito como deve ser, entendeu? Eu acredito que foi isso que fez voltar essa doença(...) B

Pelo trecho acima, é possivel perceber que este doente está constrangido. Fala no passado, de maneira hesitante, reticente, sem precisar o que ou como este passado interferiu nas interrupções do tratamento. Demonstrou arrependimento pela vida desregrada que levava, $e$ que lhe fez, no seu entendimento, "voltar a doença". As palavras remetem à idéia da tuberculose agonia romântica dos poetas, dos boêmios, a doença dos que năo se alimentam direito, que traz a morte certa, diante da qual só resta se conformar.

\section{A NEGAÇÃO E O MEDO DA DOENÇA}

Nos depoimentos abaixo, nosso entrevistado deixa claro o medo que sente em relaçăo à tuberculose cujo nome evita mencionar. A última frase de seu depoimento sugere um aviso, um apelo para não o fazer recordar o assunto.

(...)Eu não gosto nem de pensar, não gosto de falar sobre essa doença(...)Eu acho que, quando senti isso ai, fiquei aperreado, tá? Eu năo gosto de lembrar isso, tá? (...) C

Apesar da presença efetiva da tuberculose, nosso entrevistado procura escamotear o problema, atribuindo os sintomas a outra doença:

(...)Eu peguei uma gripe, tou até um pouco rouco, sabe, tou tossindo, mas não me afetou em nada(...)Eu tou bem, já recuperei o peso, só tou gripado e rouco, mas é porque cantei muito ontem. É... passei a noite cantando a mulher dos outros! C

O entrevistado rejeita o papel de doente. Admite a rouquidăo e a tosse, mas se apressa em dizer que os sintomas não o afetam "em nada", atribui a secreçăo a uma gripe decorrente de uma noite de aventuras sexuais. Abordado acerca da interrupçăo do tratamento, ele se justifica dizendo:

(...) Porque eu gosto de me tratar com remédios caseiros, năo é que eu prefiro, mas é mais doce. Tomo chá de casca de copalba, mastruz, eu não sei dizer nada...Eu năo sei se foi o remédio de vocês ou se foi o meu(...) C

Informa procurar alternativas para aliviar os sintomas, mas não se reconhece como doente. Deixa a entender ter usado o medicamento tuberculostático, embora coloque em dúvida sua eficácia. Tenta justificar a interrupção do tratamento.

(...)Năo voltei mais lá....(no CEMETRON)Eu podia ter voltado, mas viajei, cheguei sexta feira passada. Eu deixei porque viajo muito, viajo pra passar um dia, passo uma semana, um mês, ai não dá, eu năo me lembro de tomar, não vou pegar remédio pra dois, três meses porque nunca sei quanto tempo vou ficar por lá(...) C

Descreve suas viagens, como para reafirmar que se sente forte e ativo. Dizer que se sente bem, e que até já retomou sua vida normal, pode ser uma forma delicada de se esquivar de falar da insatisfação em relaçăo ao serviço que o atendeu. Demonstrou que já sabia da 
possibilidade de pegar medicamentos suficientes para vários meses, quando viajasse. Esta informação é comumente prestada nos serviços, para que não haja interrupção em caso de viagens. Sabendo disto, por que o entrevistado não se utilizava desta alternativa?

Esta indagação começa a ser respondida com o decorrer do relato:

(...) Eu vou lá, mas é que nem sei onde está o meu cartão... eu chego lá, a enfermeira vai me esculhambar, vai, eu sei que vai. Eu vou chegar, a enfermeira vai me esculhambar, da outra vez ela passou uma hora me esculhambando, ai eu fico com vergonha, né? (...) C

$\mathrm{O}$ entrevistado primeiro tenta justificar a interrupção pela perda do cartão de cadastro no CEMETRON; logo a seguir, apesar do tom jocoso que esteve presente em toda sua fala, deixa transparecer o medo que permeia sua relação com a tuberculose e com o serviço de saúde:

(...) Outra coisa, a tuberculose como é, se o cara for opinioso e não se tratar, ela volta, e volta com mais força(...)Eu, quando vim da última vez do (outro estado)...Pô, não vou mentir, se eu tiver mentindo tou me complicando mais, né? Quando tussi assim, jorrou aquela golpada de sangue coalhado, ai eu disse: 'Pronto, vou morrer' Eu tinha deixado de tomar o remédio, aí a doutora pela primeira vez me chamou no saco também, iche, nossa! Conversou comigo(...) C

Neste trecho, $\mathrm{C}$ se curva ao medo que sente da tuberculose, que surge, agora em seu discurso, mencionada pelo nome, respeitosamente, como se fosse uma entidade que castiga quem ousa não se tratar (o "opinioso"), voltando com mais força. A seguir, narra o choque do retorno dos sintomas e mais uma vez aparece um certo "engasgo" em relação ao serviço de saúde. Ele diz que pode se complicar, caso não seja sincero. Por que se complicaria? E narra mais uma advertência dada por uma profissional de saúde em relação à interrupção do tratamento:

(...)Agora, eu ia lá amanhã, juro, eu ia... já sei que da próxima vez você vem com a ambulância, já pra me levar amarrado !(...)

Fica claro o relacionamento conflituoso entre este doente e o serviço que o atendeu. Ele oscilava entre a subserviência e a rebeldia, ora negando as evidências da doença, ora se curvando a elas. Disfarçava, com brincadeiras, a relação tensa com os profissionais, ao mesmo tempo em que dizia, nas entrelinhas, que tinha medo e queria ficar bom, mas, não queria receber ordens e repreensões.

O jeito como $\mathrm{C}$ se relaciona com a tuberculose, o medo de morrer ao ver o sangue escarrado, o medo da internação, além de outros elementos inconscientes que pareciam estar a todo momento atuando enquanto conversávamos, apontam para uma atitude de interrupção de tratamento por razões que pertencem a regiões do inconsciente, onde não se penetra facilmente.

\section{A ILUSÃO DE ESTAR CURADO}

A interrupção do tratamento ocorre muitas vezes porque o doente se autodetermina curado. Em alguns casos esta cura vem com o uso dos quimioterápicos: (...)Eu fiz 2 meses de tratamento e fiquei bom, por isso não precisei mais voltar lá.(...)"K;“(...)Eu já tava no 5ำ mês de tratamento. Eu já tava melhor, achava que era besteira, ai deixei de tomar(...) A

Os trechos de depoimentos acima confirmam a importância que os sintomas representam, para legitimar a condição de doente para os entrevistados. O doente, ansioso por se ver livre dos sintomas incapacitantes que a tuberculose provoca, toma os medicamentos corretamente. Esta atitude de seguir o tratamento traz a recompensa que ele busca: 0 alívio e às vezes até a cessação dos sintomas.

Contraditoriamente, o fato de se sentir mais forte, ao invés de estimular a continuidade do tratamento, por confiar na sua eficácia, parece, nestes depoimentos, ter levado aquelas pessoas a desconsiderarem a necessidade de seguir o tratamento até o fim. Pensando estarem curadas, pararam de tomar os medicamentos. Se os efeitos dos medicamentos se dessem a conhecer mais tardiamente, então o problema estaria resolvido!? 
Este dado constitui um elemento importante para a reflexăo. Muitas vezes, no atendimento ao doente são dadas informações sobre o alivio dos sintomas e a importância de persistir no tratamento até a cura; porém, o doente não continua o tratamento. Este comportamento pode ser explicado pela ação dos medicamentos que produz um alivio nos sintomas, a ponto do indivíduo pensar que está curado. O que ocorre na verdade com o tratamento da tuberculose, é que a pirazinamida age no espaço intracelular do Mycobacterium tuberculosis, enquanto que a rifampicina e a isoniazida agem nos periodos de atividades metabólicas do bacilo, no meio extracelular. Assim, a continuidade na ingestão destes medicamentos mantém uma concentração sangüinea adequada, o que garante os efeitos bactericida e bacteriostático do medicamento sobre o bacilo (Costa, 1996).

Outras vezes, o paciente afirma estar curado pela fé. É o caso de uma jovem de 28 anos, que interrompeu o tratamento seis meses antes de nosso encontro. Ela contou que morava com a mãe e irmãos, já que o marido a abandonara, levando os filhos. Indagada por que havia interrompido o tratamento ela explicou:

(...) O que eu sei é que eu fiz o tratamento 2 meses, não senti mais nada. Deixei porque fui me tratar de outro jeito. Por que eu parei? Porque eu quis, fui para a Igreja e lá fiquei curada. Minha mãe me levou lá, ai oraram por mim, o pastor, os irmãos, eu orei pelos outros, tudo foi revelado, Deus tocava em mim e nas outras doenças. Mamãe falava bem assim: 'Vamos pra igreja, porque Deus é o médico dos médicos, ai quando foi um dia eu fui, e sem querer mesmo eu senti aquela vontade de ir (...)

$\mathrm{Na}$ verdade, ela experimentou o alivio dos sintomas freqüentemente relatado por doentes em tratamento de tuberculose, conforme discutido em páginas anteriores. Ela ainda estava vivendo o periodo de alivio quando foi persuadida pela mãe a procurar a igreja. Mesmo assim, atribui maior confiança e importância à cura ali obtida:

(...)Eles me chamaram lá na frente, ai eu fui, eles até me filmaram, passou na televisão que eu fui curada. Eu falei que me sentia ruim, que não podia nem me mexer direito, que doía tudo, botei até sangue lá na frente de todo mundo, dando testemunho. Os irmãos oraram por mim, puseram as mãos em mim, ai Deus me curou, pra mim, ele me curou mesmo, Graças a Deus(...) D

Evidencia-se, assim, a atmosfera de encantamento que envolveu a solenidade em que se deu a sua cura. No inicio de seu relato, D se refere à interrupção do tratamento por "não sentir mais nada". No trecho seguinte relata que, durante o seu testemunho, apresentou escarro sanguinolento. Convém lembrar que, no segundo mês de tratamento, já se fazem sentir os efeitos bactericida e bacteriostático dos medicamentos. Isto causa uma dúvida quanto ao que pode ter acontecido no caso desta entrevistada. Pode ter sido auto-sugestão, ou volta dos sintomas.

Para fazê-la deixar o tratamento após dois meses, também foi muito importante a acolhida, o calor humano que os adeptos da igreja demonstraram, durante a sessão de cura. Como a entrevistada mesma relatou, eles oraram por ela, junto com ela, incentivaram-na a orar pelos outros, tocaram-na, ouviram seus lamentos e anunciaram soluções. Esta atitude calorosa, para com alguém que está sofrendo, doente, faz uma grande diferença; ainda mais quando comparada ao tipo de relação entre profissionais e doentes que costumamos observar nos serviços de saúde. Prossegue em seu depoimento:

(...)Eu orei, pedi a Deus para ser libertada dessa doença, me libertar dos vícios ruins, mudar de vida, aceitar Jesus no meu coração, como uma revelação, pra eu conseguir tomar meus filhos do pai deles de novo(...)

A convicção de estar curada explicita no seu discurso, se explica pela barganha que se comprometeu a fazer, obtendo a cura milagrosa depois de renunciar a uma vida desregrada, de ociosidade, do vicio, do dinheiro fácil, que acreditava ter Ihe trazido como castigo a doença, cujo nome evita mencionar, e a perda da guarda dos filhos. 
Questionada sobre o não comparecimento ao CEMETRON a fim de confirmar sua cura, com um novo exame de escarro e por que não convidou as pessoas da casa para também fazer exames, ela respondeu:

(...)Eu já tou bem. Eu tusso só as vezes, muito de vez em quando. Eu tusso, mas não tenho catarro. (...)A Até agora não tou querendo voltar lá (no CEMETRON)não. Não tou sentindo nada, eu viajo muito, vou pro interior, viajo muito, mas se eu sentir alguma coisa, eu posso até ir lá de novo(...) D

Não consegue negar que apresenta tosse, mas faz questão de frisar que é "muito de vez em quando" e que năo apresenta secreção("catarro"). Repete que viaja muito, dando a entender que não tem tempo para retornar ao Serviço. Condiciona o retorno ao CEMETRON à volta dos sintomas.

É angustiante pensar que essa jovem mora, com mais quatro adultos, numa casa conjugada, num bairro pobre, onde os vizinhos estăo sempre por perto, diz estar curada, quando na verdade, dissemina o bacilo a cada expiração, contaminando em média, em um ano, de 10 a 15 pessoas sadias, (OPAS, 1996). Ao mesmo tempo, tentar persuadi-la a voltar ao serviço é ir contra uma certeza de cura que, se não parece muito firme em alguns momentos, tem ligação com questŏes intimas, culturais e religiosas muito delicadas, as quais não podem ser abordadas de qualquer maneira.

\section{A REVOLTA COM OS SERVIÇOS DE SAÚDE}

O trecho de entrevista abaixo deixa claro o sentimento de revolta que o doente experimenta em relação ao funcionamento da unidade de saủde à qual recorreu:

(...) onde eu moro é muito longe, não tem carro todo dia prá cidade, quando tem, eu chego no posto, é uma desorganização dos inferno, nunca tem remédio, nem médico, nem nada. Se quer saber, é só isso que eu tenho a dizer(...). I

Percebe-se claramente a revolta deste ator social relatando um pouco da situaçăo em que vivem as populaçőes que moram na periferia da cidade: deficiência do sistema de transporte público, desorganização da unidade de saúde, constantes faltas de medicamentos. Em sua fala, o "remédio" vem em primeiro lugar, o que parece ser uma relativizaçăo do valor da figura do médico.

A revolta deste entrevistado em relação ao atendimento prestado nas Unidades de saúde tem razões concretas, que merecem ser explicadas. Depois das eleições para prefeito, em 1996, quando ganhou o candidato da oposiçăo, ocorreram várias mudanças no secretariado, na assessoria, nos cargos de chefia e direçăo das unidades de saúde. Essas mudanças tumultuaram os serviços. Os postos foram fechando, um a um, por greves, protestos dos profissionais pela falta de material e de segurança, pelos salários baixos e atrasados por meses a fio. Os postos de saúde de Porto Velho estiveram fechados, total ou parcialmente, de novembro de 1996 até meados de 1997. Alguns funcionaram precariamente, outros foram totalmente fechados.

Mas, I poderia ter retornado ao CEMETRON, onde havia sido atendido primeiro. Por que não o fez? Talvez por constrangimento em retornar depois de ter sido aconselhado a procurar o posto perto de casa, receio de comparecer a um serviço e falar mal de outro. Isto é comum acontecer, porque, muitas vezes o profissional que atende esses doentes no CEMETRON verifica o endereço constante da ficha de cadastro e aconselha o doente a continuar o tratamento no posto que fique mais perto de sua casa, por questão de comodidade. Neste caso, o conselho dado com a intençăo de garantir a continuidade do tratamento, acabou sendo contra-producente.

Não há nas fichas desse doente registros que indiquem que o CEMETRON tenha verificado, junto aos profissionais dos postos de saúde para onde o cadastrado havia sido encaminhado, se foi atendido e se continuava em tratamento. Rotinas neste sentido favorecem um entrosamento 
maior entre as unidades de saúde, possibilitando uma troca de informações mais detalhadas sobre casos como este; ainda mais em um contexto de crise no qual se encontrava a rede municipal de saúde, com poucos postos funcionando em precárias condições.

\section{MAIS ALGUMAS REFLEXÕES}

No trabalho de campo, por vezes, algumas atitudes dos sujeitos participantes deste estudo provocavam em nós sentimentos contraditórios, tais como: piedade, revolta, tristeza, alegria, os quais tentávamos racionalizar em constantes reflexões. Eles dialogavam conosco, recusavam-se a nos receber, faziam cobranças e exigências, brincavam, impunham condições para responderem às perguntas, dando a impressão de arrogância. Por outro lado, pareciam não ser protagonistas da própria história. Pareciam exercer uma liberdade que só se expressava no que se refere a manter hábitos e formas de viver aos quais estavam acostumados, mesmo que isto trouxesse prejuizos a própria saúde ou a dos demais. Desempregados ou explorados pelos patrões, viviam em condiçőes de miséria e pareciam não mais se dar o direito de "espernear" indignados, contra todo esse jeito ruim de viver e criar os filhos. Tudo isso nos levou a questionar se para eles esse jeito de viver é ruim mesmo, se é o único que conhecem, se a tuberculose e o sofrimento que causa combinam bem com aquele modus vivendi.

Lendo, refletindo e interagindo com esses atores sociais, aprendemos fortes lições. Compreendemos que, ao tomarem tais atitudes, estão dizendo que são e querem continuar sendo protagonistas de sua própria história, embora esta não seja a história que os profissionais de saúde almejam. Como tal, se asseguram do direito de preservar os próprios valores, o jeito próprio de viver e exercer seus costumes, de acordo com suas próprias regras e prioridades. Querem, na verdade, é se manter livres do cárcere da internação compulsória, do pesado esquema terapêutico que o tratamento exige e das regras rigidas que os profissionais e os serviços de saúde Ihes impõem.

Inferimos que muitos deles estavam, pela primeira vez, tendo a chance de mostrar um pouco de si mesmos, seus medos, suas razões, valores e ilusões. Talvez ansiassem por uma oportunidade como esta que o estudo lhes proporcionou, para dizerem o que já queriam dizer há mais tempo, mas não lhes era permitido no espaço institucional, "terreno" dos profissionais. Este é o jeito de "espernear" deles, e a tuberculose não combina com nada disso. Talvez a tuberculose combine mais com a maneira como estão organizados muitos de nossos serviços de saúde.

Entendemos a interrupçăo do tratamento da tuberculose como um desafio que engloba uma série de facetas relacionadas à limitada eficácia dos programas de controle da tuberculose e à crise em que estão mergulhados os serviços de saúde que atendem esses doentes; às características da própria tuberculose, que carrega ainda fantasmas remanescentes da época em que dividia com a sífilis o papel de doença metáfora; ao modo como o bacilo se comporta frente ao tratamento, quando os sintomas desaparecem e o impacto que isso causa no doente; ao contexto político-social em que doentes e profissionais vivem. Além disso, há também questőes da subjetividade dos profissionais e dos doentes.

Inferimos ainda que a interrupção voluntária do tratamento está intimamente relacionada com a maneira como se processou o adoecimento, como se deu a procura por ajuda, se houve diálogo e como se entrelaçaram o seu discurso e o do profissional que o recebeu na unidade, tanto no momento da descoberta dos sintomas e da procura por ajuda, quanto posteriormente, no modo como se deu o enfrentamento da doença. Em outros termos, os motivos da interrupção voluntária tocam em dimensőes da alma que não são facilmente explicáveis. Para fazer uma análise que penetre nessas dimensões, nós teriamos a necessidade da utilização de um referencial teórico-metodológico especifico que não foi por nós estudado, por distanciar-se do objeto de estudo desta pesquisa.

Embora sem o referido instrumental, inferimos que muitas explicações estão na dimensão 
do não dito, tanto quanto no que foi dito como motivo de interromper o tratamento. Entendemos que algumas daquelas pessoas, ao serem impelidas pelos sintomas a procurar por ajuda, ficaram caladas no que se refere àquilo de mais profundo, nebuloso e inexplorado que possuem dentro de si; talvez por não terem clareza dos movimentos interiores que o adoecer Ihes provocava, ou por não poderem conter a torrente de emoções que desencadeavam o confronto com o diagnóstico e a imposiçăo de um tratamento prolongado e permeado de dificuldades.

A doença é uma experiência difícil para qualquer um de nós. Coloca-nos em contato com muitas sensaçőes temiveis e desconhecidas, até porque através dela constatamos nossa finitude. A ameaça que a doença faz a nossa integridade se mostra, tanto externamente, por abalar hábitos e comportamentos já enraizados em nosso cotidiano e em nossas relaçőes, quanto internamente, por modificar a percepção que temos de nós mesmos, de nossas capacidades, desejos e ansiedades. A doença dói no nosso corpo, no nosso bolso e também na nossa dignidade, já que abala diretamente a nossa principal fonte de sustento, a força de trabalho. Nessa experiência, os profissionais de saúde têm uma participação cada vez mais importante, embora muitas vezes seja negligenciada, ou talvez uma atitude aparentemente descuidada, como forma de se preservar do sofrimento

Alguém já disse que o sofrimento é contagioso, dai a dificuldade de interagir com pessoas que estão sofrendo sem que soframos juntos. Nossas convicçőes e anos de estudo parecem balançar à nossa frente, consequentemente, nossos compromissos profissionais passam a ser questionados. Enfrentar tal fragilidade e reconhecer nossos limites são atitudes que exigem coragem. Talvez venha dai algum sentido para justificar a protetora abordagem biológica ou a necessidade do distanciamento científico nas relaçőes com doentes de tuberculose. Assim, durante a realizaçăo das entrevistas ou na prática profissional, enquanto estivermos pensando apenas nos pulmões doentes, estaremos preservados de sofrimento.

Protegidos ou não, estamos diante de um desafio: o doente necessita expressar suas aflições e espera que o profissional the escute e responda aos anseios mais urgentes, conforme 0 trecho a seguir:

É no quente da dor física que se deve falar. Nada mais traidor, com efeito, que o sofrimento físico, nada que se furte mais à análise. É no fogo da ação, na hora $\mathrm{H}$, que convém captá-lo(...) por violenta e imperiosa que seja a dor física, logo que sumiu não passa de má lembrança.(...)é no próprio momento em que roe (sic) e aniquila que é preciso pegá-la. É durante a doença que é preciso falar na doença. Após a cura, as impressőes ficam vagas, imprecisas, sem vigor nem cor...é inegável que não se pode falar bem em moléstia, senão de dentro. Isto implica que se possa aproveitar, para notar tudo que vale a pena, os menores momentos em que o sofrimento afrouxa...

Este depoimento dramático sobre a vivência do adoecer de Raymond Guérin, citado por Lepargneur (1987, p. 80), nos dá uma idéia do quão forte pode se fazer sentir o discurso que a doença provoca, para o indivíduo que a está vivenciando. Mas, como trazer à razăo algo não racional, posto que se impõe mediante sensações, como a doença? Talvez o discurso comece a ser construído ainda no "quente da dor física", embora de maneira confusa, mas só se faça claro depois da situaçăo vivida, ainda que não totalmente superada.

O discurso que emerge do sofrimento nem sempre é valorizado no relacionamento profissional $X$ doente, a exemplo do que aconteceu com os sujeitos deste estudo, que queriam falar da dor que sentiam, enquanto ela ainda Ihes roia e aniquilava; do choque que sentiram, quando começaram a se descobrir doentes. Mas não encontraram quem os escutasse, o máximo que encontraram foi alguém que Ihes desse o diagnóstico preciso. $E$, encontrando, usufruiram da assistência, cada um a sua maneira, até o momento em que, por motivos explicáveis ou não, interromperam o tratamento.

Todo o conhecimento acumulado sobre as doenças foi construido com a ajuda da verbalizaçăo do enfermo sobre sua experiência de adoecimento. Mas, nem sempre isto é levado 
em conta, no cotidiano da assistência à saúde. O profissional, às vezes, tende a prescindir da contribuiçăo da fala do doente, confinando a relaçăo com o doente àquele momento em que o está atendendo, talvez para afastar-se da situaçăo, para melhor avaliá-la, mas, por vezes tal afastamento pode causar uma análise fragmentada de uma realidade que é mais profunda e complexa do que parece.

Esta avaliaçăo fragmentada cria lacunas no enfrentamento da doença. O diálogo tende a virar um interrogatório, cujas perguntas nem sempre săo esclarecidas e as respostas nem sempre levadas em conta, no atropelo do atendimento nas unidades de saúde. Talvez este hiato entre o discurso do doente e o do profissional seja mais um ponto em que se desenha a interrupção do tratamento.

A fala do doente e a fala do profissional de saúde nem sempre se coadunam; um ouve o que o outro diz com a ajuda de um "filtro", que deixa passar aquilo que lhe interessa do discurso do outro, que é interpretado e utilizado de acordo com as próprias necessidades. Ambos seguem lógicas diferentes, ligadas a sinais também diferentes. Para o doente, os sinais são sentidos; para o profissional que o assiste, os sinais são vistos, observados. Ouvir alguém falar da dor que sente, e sentir a dor nunca serão a mesma coisa. O impasse continua.

A questão que se coloca agora é: por que o encontro entre o doente e o profissional que o atende é tăo dificil? Talvez porque o diálogo é mesmo algo dificil de ser exercitado. De qualquer modo, devemos atentar para o fato de que entre o que nós falamos e aquilo que o outro ouve, há um espaço vazio. De acordo com a disposiçăo interior dos dois sujeitos do diálogo, este espaço pode ser um abismo insondável e ameaçador que inviabiliza qualquer aproximaçăo, ou um fosso, cuja profundidade pode ser avaliada e diminuida, num laborioso exercicio a dois.

Talvez uma saida para o impasse estabelecido no relacionamento profissional $X$ doente possa ser vislumbrada com a contribuiçăo que a Antropologia pode prestar à atençăo à saúde. Isso porque, se năo compreendermos os complexos processos subjetivos que envolvem o adoecer, a busca de tratamento e a năo adesăo ao tratamento institucionalizado, talvez 0 espaço que separa profissional e doente seja o abismo antes referido.

Para Alves e Minayo (1994), năo se pode contestar a importância da antropologia para se compreender o fenômeno saúde-doença. Os dados quantitativos e os conhecimentos técnicos e científicos săo inegavelmente imprescindiveis; porém, os valores, crenças e atitudes de uma populaçăo também devem ter sua relevância reconhecida, ao se desenvolver qualquer ação em relaçăo à saúde, seja nas fases de planejamento, prevençăo ou tratamento. A doença é, ao mesmo tempo, um fenômeno clinico e sociológico, já que expressa as afliçőes e agruras presentes no corpo individual e também no corpo social, evidenciando as inquietações do homem como ser total. A enfermidade reflete e cristaliza os modos como a sociedade experimenta, em conjunto, seu medo frente à morte e seus próprios limites ante o mal. A doença é importante, tanto por seus efeitos biológicos quanto pelos efeitos que causa no imaginário. Ambos são reais à luz da antropologia. O doente é um personagem social e a doença é uma realidade construida.

Por outro lado, no movimento saúde-doença e na interrupçăo de tratamento de tuberculose, há também questőes que tocam em outras áreas de conhecimento, além da antropologia. Cada profissional sabe, ou deveria saber, a contribuiçăo que pode dar e o lugar que ocupa no atendimento aos doentes. $\mathrm{O}$ fato é que há pessoas doentes interrompendo o tratamento, ora por motivos ligados à organização dos serviços, ora por motivos nem sempre explicáveis ou facilmente sanáveis, fazendo a tuberculose recrudescer cada vez mais forte, a despeito dos recursos disponiveis e do apoio da mídia. Contraditoriamente, săo veiculadas através dos meios de comunicaçăo social campanhas que reforçam a idéia de que a saúde é responsabilidade individual, reduzindo o combate à tuberculose à divulgaçăo dos sinais e sintomas e à obrigatoriedade de cumprir "tudo que o médico mandar", como se a questăo fosse simples assim. 
Reconhecemos a importância de uma discussão mais ampla e aprofundada, sobre as abordagens que utilizamos no relacionamento com os doentes de tuberculose e a interrupção de tratamento, com a contribuição das Ciências Sociais. O binômio tuberculose/interrupção de tratamento se apresenta, diante de nós, como um desafio que cada vez mais nos conclama a rever nossas posições teóricas e metodológicas.

A compreensão cultural contribui para alargar nosso campo de visão. Ao oferecer outras alternativas de foco, desvia nosso olhar historicamente condicionado aos fatores evidenciados pelo modelo biomédico. Este desvio não se dá na perspectiva de desvalorizá-los, mesmo porque o trabalho dos profissionais de saúde é feito também a partir do reconhecimento dos agentes etiológicos, sinais, sintomas, contágio, tratamento e prevenção, mas para que os fatores biológicos sejam vistos como integrantes de uma realidade ainda mais rica e complexa, em que se inserem a saúde, 0 adoecer e a morte. Esta perspectiva pode trazer à tona aspectos da interrupção de tratamento da tuberculose que merecem uma investigação mais profunda, com instrumentais que proporcionem um mergulho mais bem direcionado, com amplitude visual maior, para explorar as hesitações, reticências, descobertas e perplexidades do individuo que se descobre doente $\mathrm{e}$, a despeito de todos os fatores que aparentemente parecem garantir a continuidade, interrompe o tratamento

ABSTRACT: This study of tuberculosis patients who interrupt their treatment was carried out in the city of Porto Velho (RO) motivated by my belief that the interruption of this treatment is a challenge to collective health, due to the difficulties which health professional face with respect to the treatment and control of tuberculosis. The adopted qualitative approach and the use of the dialectic-hermeneutic method of analysis of the material, collected through interviews, led me to infer that the subjects of this study possessed little knowledge of tuberculosis, revealing the adoption of attitudes related to the impact which to the diagnosis and the prolonged treatment caused them and the social environment in which they live. For the twelve patients who participated in this study, the motives for interruption of treatment were related to reasons rooted in the non-spoken and in causes like the collateral effects of medicines, the disorganization of services and the illusion of being cured. This has important implications for our technical-methodological positions and for the patient-professional relationship, in our search for an approach which allows us to face the binomial tuberculosis-interruption of treatment as experiences undergone by patients, families and the social networks constructed by them over time.

KEYWORDS: tuberculosis, treatment interruption, Collective Health

RESUMEN: Estudio realizado en Porto Velho (RO - BRASIL), junto a los enfermos de tuberculosis que interrumpieran el tratamiento. A partir del abordaje calitativo y del método hermenêutico-dialéctico de análisis del material de las entrevistas, fue posible inferir que los sujetos del estudio tienen poco conocimiento sobre tuberculosis y toman actitudes relacionadas al impacto que el diagnóstico y el tratamiento prolongado causaran a ellos proprios y al su medio social. Para los doce entrevistados, la interrupcón del tratamiento relacionase a los motivos enraizados al no dicho, efectos colaterales de los medicamentos, desorganizacón de los servicios e ilusión de estar curado. Esto implica en que repensermos nuestras posiciones técnico-metodológicas y las relaciones professionalenfermos, visan a un abordaje que possibilite mirar la tuberculosis-interrupción del tratamiento como experiencias vividas por las personas, familia y redes sociales por ellos tejidas a lo largo del tiempo.

PALABRAS CLAVE: tuberculosis, interrupción de tratamiento, Salud Colectiva. 


\section{REFERÊNCIAS BIBLIOGRÁFICAS}

ALVES, A.R. et al. Saúde e Doença: uma abordagem sócio-cultura,l in: SILVA, Y.F. \& FRANCO, M.C.(org.) Saúde e Doença: Uma Abordagem Cultural da Enfermagem. Florianópolis: Papa- Livro, 1996. $120 \mathrm{p}$.

ALVES, P. C. \& MINAYO; M.C.S. Saúde e Doença: um Olhar Antropológico. Rio de Janeiro: FIOCRUZ, 1994.

BELTRAN, O.R.P.; MOSCA, E.A.; CROSS, A. El abandono del tratamiento en tuberculosis: realidad actual e perspectivas futuras. Rev. Arq. De Tuberculosis, Enfermidades y Salud Publica, v. 41 n.1, p. 11-21, 1983.

BRASIL, Ministério da Saúde. Manual de normas para o controle da tuberculose. 4. ed., Brasilia: FNS/ Centro Nacional de Pneumologia Sanitária, 1995.

Ministério da Saúde. Recomendações sobre Pontos Polêmicos em Tuberculose. Oficina de trabalho. Coordenação Nacional de Pneumologia Sanitária-FNS-MS, Sociedade Brasileira de Pneumologia e Tisiologia-SBPT, Brasilia, 1997(mimeo.) 54p.

COSTA, M.F.A. Fatores operacionais e sociais envolvidos no abandono terapêtico da tuberculose no município de Manaus(AM). João Pessoa: Universidade Federal da Paraiba-UFPb, 1996, Dissertação de Mestrado.

DEMO, P. Metodologia Científica em Ciências Sociais. 2. Ed. Rev. Amp. São Paulo: atlas, 1989. , Metodologia cientifica em Ciências Sociais. 3. Ed. São Paulo: atlas, 1995.

FERRER, X. \& KIRSCHBUM, T. et al. Adherencia al Tratamiento del Adulto en Santiago del Chile. Bolletín de la Oficina Sanitaria Panamericana. OPAS, v. 1, n. 5 p. 423-31. Washington, 1991.

GIL, A.C. Métodos e Técnicas de Pesquisa Social. São Paulo: Atlas, 1990. 207p.

LEPARGNEUR, H. O doente, a doença e a morte: Implicações sócio-culturais da enfermidade. Campinas: Papirus, 1987, 208 p.

MINAYO, M.C.S. O Desafio do Conhecimento-Pesquisa Qualitativa em Saúde. 4. ed. São Paulo-Rio de Janeiro: HUCITEC-ABRASCO, 1996.

ORGANIZACION PANAMERICANA DE LA SALUD. La Tuberculosis: Grave Peligro para la Humanidad Boletín de la Oficina Sanitaria Panamericana. V.120, n.4, p.327-8, 1996.

PEREIRA, W.S.B. Como a Enfermagem pode se Expressar na Educação? 1996(mimeo.)

PINKUS, L. Psicologia do Doente. São Paulo: Paulinas, 1988

SAMPAIO, D.B.; DUARTE, M.B.; GUERRA, C. et al. Razões do paciente para abandono no tratamento da tuberculose. Boletim Epidemiológico, Salvador, SESAB/SUS. v. 10, n. 8. P 3 junho, 1994.

VALLA, V.V.\& STOTZ, E.N.(org). Participação popular, educação e saúde: teoria e prática. Rio de Janeiro: Relume- dumará, 1993 159p. 